DOI 10.37882/2223-2982.2020.09-2.04

\title{
ПОКАЗАТЕЛИ И КРИТЕРИИ ОРГАНИЗАЦИОННОЙ ОЦЕНКИ ИНОЯЗЫЧНОЙ КОММУНИКАЦИИ ОФИЦЕРА СУХОПУТНЫХ ВОЙСК: НЕКОТОРЫЕ АСПЕКТЫ
}

\section{INDICATORS AND CRITERIA \\ ORGANIZATIONAL ASSESSMENT OF \\ FOREIGN LANGUAGE COMMUNICATION OF TNE ARMY OFFICER: SOME ASPECTS \\ V. Bikbaev}

Summary:The article discusses the criteria and indicators of organizational evaluation of foreign language communication officer in the professional development of the officer. It is noted that socio-professional and military-professional activities, as well as personal factors have a great influence on the formation of foreign language communication officer. When considering the criteria and indicators of organizational evaluation of foreign language communication, it is important to assess the educational opportunities of professional training, self-education and the system of professional development of military personnel. It is indicated that the factors of formation of foreign language communication are divided into three main groups: organizational-pedagogical, socialprofessional, organizational-professional.

Keywords: organizational assessment, improvement of foreign language communication, factors of formation of foreign language communication, social and professional environment.

\author{
Бикбаев Вадим Манцурович \\ К.полит.н., дочент, Новосибирское высшее \\ военное командное училище \\ vadim_bikbaev@mail.ru
}

Аннотация: В статье рассматриваются критерии и показатели организационной оценки иноязычной коммуникации офицера в рамках профессионального становления офицера. Отмечается, что социальная ситуация и военнопрофессиональная деятельность, а также личностные факторы оказывают большое влияние на формирование иноязычной коммуникации офицера.

При рассмотрении критериев и показателей организационной оценки иноязычной коммуникации важна оценка образовательных возможностей профессионально-должностной подготовки, самообразования и системы повышения квалификации военнослужащих. Указано, что факторы формирования иноязычной коммуникации разделены на три основные группы: организационно-педагогические, социально-профессиональные, организационно-профессиональные.

Ключевые слова: организационная оценка, совершенствование иноязычной коммуникации, факторы формирования иноязычной коммуникации, соцально-профессиональная среда.

Подготовка квалифицированных военных кадров и разᄀвитие системы военного образования являются приоритетᄀными задачами Министерства обороны России и важнейшилми направлениями деятельности военных образовательных учреждений для обеспечения обороноспособности нашего государства. В настоящее время система военного обралзования - это отлаженный и эффективно работающий механизм, задачей которого является подготовка, професлсиональная переподготовка и повышение квалификации военных кадров [3, с. 4 - 14].

Следует отметить, что важно не только определение условий и факторов формирования иноязычной коммуникации офицеров, но и выявление взаимосвязи и взаимозависимости каждого из заранее отобранных факторов с эффективностью процессов формирования иноязычной коммуникации офицера Сухопутных войск. 
Как указывала в этой связи И.Л. Бим, современная эффективная образовательная среда при обучении иностранному языку связана с окружением учителя и ученика как субъектов процесса обучения и того, что специально вовлекается в это окружение [1].

На наш взгляд, необходимо подчеркнуть, что военно-профессиональная деятельность и сама социальная среда, с одной стороны, - оказывают непосредственное влияние на формирование иноязычной коммуникации, с другой - в некоторой степени передают и видоизменяют влияние на иноязычную коммуникацию других факторов.

Большое значение, как совершенно верно указывает Степанова Н.В., играет опора на личностный опыт в образовательном процессе благодаря использованию в ходе обучения личностно ориентированной педагогической (учебной) ситуации (эффективный педагогический механизм, благодаря которому появляются новые условия, требующие от обучаемого иную «модель поведения») [12, с.143 - 146].

На современном этапе развития вооруженных сил исследование влияния среды и деятельности в данном контексте приобретает особую актуальность, так как в ходе взаимовлияния социальной среды и военно-профессиональной деятельности наиболее отчетливо видна проблема рассмотрения и понимания сущности взаимодействия субъекта (человека) с окружающей средой, с постоянно меняющимся миром, где языковая образовательная среда представляет системно образованное пространство, в котолром реализуется взаимодействие субъектов образователь ᄀного процесса как «вторичных» языковых личностей (курлсант, офицер, сержант, преподаватель, курсовой офицер и др.) с внешней средой (рода войск, военные подразделления, международные операции и др.), в результате чего раскрываются индивидуальные профессионально значи-мые черты личности обучающихся посредством аутентич ᄀного языкового учебного материала на иностранном языке как учебном предмете, что способствует эффективности их речевого взаимодействия [6, с.159, 7].

Как совершенно верно указывают исследователи, рассмотрение социально-профессиональной среды вызвано тем, что она способна к самовыдвижению развивающейся личности, в том числе за счет своей способности оказывать большое влияние на профессиональное становление специалиста [10], [11].

В ряде научных работ исследование условий военно-профессиональной деятельности согласуется с нормативностью и универсальностью основных положений ведущего деятельностного подхода к пониманию процессов развития личности [2], [4], [8], согласно которому деятельность выступает условием и средством развития личности, а социально-профессиональная среда, которая способна ускорять или замедлять процессы профессионального становления, становится объектом исследования и педагогического управления [13].

Исходя из анализа факторов формирования иноязычной коммуникации офицера Сухопутных войск (как личностных и профессионально-ориентированных, так и психологических и педагогических), их можно разделить на следующие группы:

- профессионально-языковые (организационные и педагогические), которые реализуются в ходе языковой подготовки и непрерывного профессионального образования;

- социально-профессиональные, формирующиеся непосредственно в повседневной жизнедеятельности военнослужащих (в рамках языковых курсов и других мероприятий в воинском коллективе, во время которых необходимы не только знания, но и определенные навыки и умения владения иностранным языком для выполнения профессиональных задач);

- организационно-профессиональные, влияющие в определенной степени на карьеру военнослужащего и являющиеся в результате этого своего рода стимулами в системе управления кадрами Сухопутных войск Вооруженных Сил Российской Федерации (рисунок 1).

Следует подчеркнуть, что, несмотря на доступность образовательных ресурсов и программ, обеспечивающих совершенствование иноязычной коммуникации курсантов и офицеров, в силу ряда условий военно-профессиональной деятельности (отсутствие необходимого свободного времени и загруженностью по службе) военнослужащие не могут воспользоваться ими в полной мере.

Для более детального рассмотрения данного критерия, на наш взгляд, необходимо рассмотреть три показателя: доступность образовательных программ, доступность открытой информационной среды и условия для самообразования.

1. Доступность языковых образовательных программ.

Например, во время обучения как курсанта, так и офицера следует оценивать не только наличие запланированной программой языковой учебной дисциплины, но и возможность изучения иностранного языка в рамках дополнительного профессионального образования и иных форматов обучения и воспитания военнослужащих (научны 


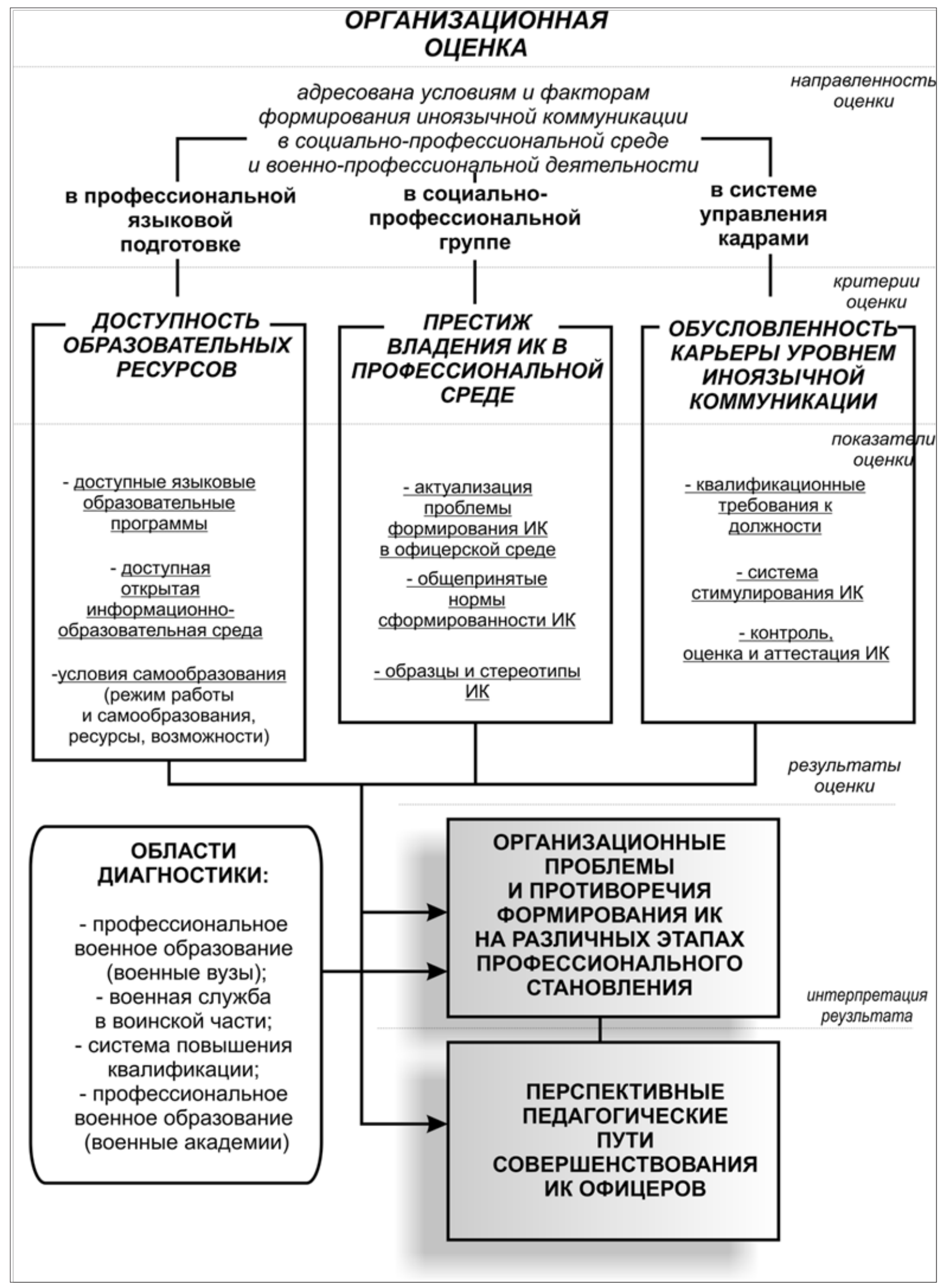

Рис. 1. Схема организационной оценки иноязычной коммуникации офицера Сухопутных войск 
исследований, проектов и до.). Следует отметить, что важна оценка образовательных возможностей профессионально-должностной подготовки военнослужащего, а также самообразования и системы повышения квалификации;

2. Доступность открытой информационно-образовательной среды. Формирование иноязычной коммуникации как специально организованный педагогический процесс достаточно давно характеризуется тенденцией расширения информационно-образовательных ресурсов языковой подготовки, в т.ч. открытых и общедоступных платформ. Вместе с тем, в военных образовательных средах, где важны вопросы защиты государственной тайны, только нарабатываются механизмы обеспечения доступности при постоянно возрастающих ограничениях. На наш взгляд, можно утверждать, что система защиты государственной тайны (инфраструктура, механизмы, технологии, регламенты) не отвечает уровню современно й информатизации профессионального образования. Открытая образовательная среда, по факту, открыта весьма условно. В информатизации непрерывного профессионального образования проявляются противоречия, которые весьма сдерживают ее и, в отсутствие единых решений, пока преодолеваются по-разному. Военные вузы могут радикально отличаться в подходах к обеспечению доступа военнослужащих к открытой информационно-образовательной среде, а в военных частях, в большинстве случаев, эта проблема даже не обсуждается;

3. Условия самообразования. Признавая безусловное значение самообразования, руководство Вооруженными Силами Российской Федерации в настоящее время сосредоточено на создании материальных ресурсов самообразования взамен устаревших и утративших свое значение советских. Однако следует признать, что без внимания остаются физические возможности самообразования, связанные с наличием свободного времени и загруженностью по службе. Признавая эти условия важными для формирования иноязычной коммуникации офицеров Сухопутных войск, мы выделили их в отдельный показатель организационной оценки.

Необходимо подчеркнуть, что большое значение при изучении иностранного языка играет индивидуальность (личностная первооснова), в связи с чем организационная диагностика включает условия и факторы самой социальной и военно-профессиональной среды, которые мотивируют процессы формирования иноязычной коммуникации $[5,9,16,17]$.
Основная оценка в данном случае сосредоточена на уровне макросреды - т.е. среди офицеров конкретной военной организации (военного вуза и др.). Мы, безусловно, учитываем настроения и ориентации всего офицерского корпуса Сухопутных Войск Российской Федерации, характеризующие его как макросреду, но признаем, что ее трансляция в условиях конкретной воинской части может весьма существенно различаться. В целом, влияние социально-профессиональной среды объединяет в себе социально-психологические механизмы развития личности, среди которых, в связи с предметом нашего исследования, мы выделяем престиж владения иноязычной коммуникацией, тесно переплетающийся с авторитетом и уважением. Следует отметить, что престиж является относительной характеристикой, тесно связанной с общественным мнением и сознанием.

На наш взгляд, существует три главных показателя, через которые может рассматриваться престиж: актуализацию иноязычной коммуникации, нормы ее сформированности, а также стереотипы и образцы.

1. Актуализация проблемы иноязычной коммуникации офицера Сухопутных войск является своего рода осознанием военнослужащими повышения роли и значения иноязычной коммуникации в военном деле с учетом перспектив его развития, «порождающий» общие, разделяемые большинством смыслы профессионального становления, связанные с ее формированием [14, 15].

2. Общепринятые нормы сформированности иноязычной коммуникации представляют собой одобряемые в офицерской (курсантской) среде модели иноязычной коммуникации, главным критерием которых является способность к осуществлению;

3. Установившиеся в воинском коллективе образцы и стереотипы иноязычной коммуникации, которые предполагают наиболее распространенные способы решения профессиональных задач с использованием иноязычной коммуникации, могут способствовать или ограничивать процесс формирования иноязычной коммуникации.

Таким образом, организационная оценка по замыслу диагностического исследования создает представления о проблемах противоречиях процесса формирования иноязычной коммуникации офицеров Сухопутный войск. В дальнейшем, в сочетании с прогностическими исследованиями иноязычной коммуникации, на ее основе возможно определение перспективных путей решения проблемы. 


\section{ЛИТЕРАТУРА}

1. Бим И.Л. Методика обучения иностранным языкам как наука и проблемы школьного учебника М. : Русский язык, 1977. 288 с.

2. Выготский, Л.С. Педагогическая психология / Л.С. Выготский. - М.: Педагогика, 1991. - 480 c.

3. Горемыкин В.П. Военное образование - цель на развитие // Вестн. военного образования. № 1 (4), январь-февраль 2017 г. М. : Красная звезда М0 России. С. 4-14.

4. Леонтьев, А.Н. Деятельность. Сознание. Личность / А.Н. Леонтьев. - М.: Академия, 2005. - 352 с.

5. Мясищев В.Н. Структура личности и отношения чело ᄀвека к действительности // Психология личности: Тексты / под ред. Ю.Б. Гиппенрейтер, А.А. Пузырея. М.: Изд-во Моск. ун-та, 1982. С. 35-38.

6. Некрасова Т.В. Личная направленность языковой образовательной среды военного вуза как эффективное средство профессиональной коммуникации курсантов. // Гуманитарные исследования.№3(24), 2019. C. 159 - 161. D0l: https://doi.org/ 10.36809/2309-9380-2019-24-159-162.

7. Ромм, Т.А. Теории социального воспитания: перспективы развития / Т.А. Ромм // Педагогический журнал Башкортостана. - 2013. - № 6 (49). С. $64-68$.

8. Рубинштейн, С.Л. Основы общей психологии / С.Л. Рубинштейн. - СПб.: Питер, 2002. - 720 с.

9. Сериков В.В. Личностный подход в образовании: кон-цепция и технологии: Монография / В.В. Сериков. Волгогр. гос. пед. ун-т. - Волгоград: Перемена, 1994. - 150 c. ISBN 5-88234-061-6 https://search.rsl.ru/ru/record/01001702158.

10. Соловьев, И.О. Развитие профессионала в акмеологической среде: автореф. дис. ... д.пс.н.: 19.00.13 / Соловьев Игорь Олегович. - М., 2011. - 58 с.

11. Солянкина, Л.Е. Психолого-акмеологическая концепция развития профессиональной компетентности специалиста в практико-ориентированной образовательной среде: автореф. дис. ... д.пс.н.: 19.00.13 / Солянкина Людмила Егоровна. - Тамбов, 2011. - 50 с.

12. Степанова, Н.В. Генезис разработки идеи учета индивидуальных особенностей личностно ориентированного образования. // Актуальные проблемы современной науки в 21 веке: сборник материалов 3-й международной научно-практической конференции. - Махачкала, 2013. C. 143-146. URl:https:// elibrary.ru/item. id $=22769423$.

13. Тихонина, С.А. Профессиональная среда государственной гражданской службы как объект управления: социологический анализ: автореф. дис. ... д.социолог.н.: 22.00.08 / Тихонина, Светлана Алексеевна. - Нижний Новгород, 2006. - 49 с.

14. Фадейкина, 0.В. Формирование иноязычной коммуникативной компетентности будущих офицеров: автореферат дис. .... кандидата педагогических наук: 13.00.08 / Уральский гос. пед. ун-т. - Екатеринбург, 2001. - 20 с.

15. Ценева, И.В. Формирование культуры иноязычной коммуникации будущих офицеров: На примере преподавания немецкого языка: диссертация ... кандидата педагогических наук: 13.00.08. / Уральский гос. пед. ун-т. - Екатеринбург, 2006. - 210 с.

16. Якиманская Н.С. Основания для построения педагогической диагностики в рамках личностно-ориентированного образования. // Материалы V Международной научно-практической конференции. Под редакцией Н.Н. Михайловой, И.В. Хромовой. 2017 С. 245-254.

URI:https://elibrary.ru/item. id=32521044.

17. Personality and Intelligence / Ed. By R. Sternberg \& Ruzgis. N.Y., 1994. -458 c.

(с) Бикбаев Вадим Манцурович (vadim_bikbaev@mail.ru)

Журнал «Современная наука: актуальные проблемы теории и практики» 